\title{
Regulation of Adiponectin and its Receptors by Endogenous and Exogenous Factors
}

\author{
Hassanpour SH${ }^{1}$, Dehghani MA ${ }^{2}$, AlipourSM${ }^{3}$ and Karami SZ ${ }^{4}$ \\ ${ }^{1}$ Young Researchers and Elite Club, Yasooj Branch, Islamic Azad University, Iran \\ ${ }^{2}$ Department of Toxicology, Ahvaz Jundishapour University of Medical Sciences, \\ Iran \\ 3Department of Environmental Health, Yasouj University of Medical Sciences, Iran \\ ${ }^{4}$ Department of Biology, Yasouj University, Iran
}

\section{Review Article \\ Volume 3 Issue 1}

Received Date: January 26, 2018

Published Date: February 09, 2018

DOI: $10.23880 /$ doij- 16000174

*Corresponding author: Seyyed Hossein Hassanpour, Young Researchers and Elite Club, Yasooj Branch, Islamic Azad University, Yasooj, Iran, 7591181963, Tel: +98 9171452844; Fax: +98 7433372379; E-mail: Dr.hossein1366@yahoo.com

\begin{abstract}
Adiponectin is a hormone-derived adipose tissue. There is two form of adiponectin as low molecular weight (LMW) and high molecular weight (HMW). It has important role in energy homeostasis and is related to disease such as insulin resistant and obesity. In fact, the fluctuant in its serum level is affective in abnormality of energy homeostasis. Here, we reviewed the effect of both endogenous and exogenous factors on regulation of adiponectin. Based on our review, adiponectin and its receptors can consider as special therapeutic targets to treat diabetes, obesity and cardiovascular disease.
\end{abstract}

Keywords: Adiponectin; Adipose tissue; Insulin resistant; Obesity

Abbreviations: LMW: Low Molecular Weight; HMW: High Molecular Weight; AMPK: Adenosine Monophosphate Protein Kinase; ACC: Acetyl Coenzyme a Carboxylase; PPAR: Peroxisome Proliferators Activated Receptor; SREBP1c: Sterol Regulatory Element-Binding Protein 1c.

\section{Introduction}

Adiponectin has been identified as an adipocyte complement-related protein that obtained from murine 3T3-L1 adipocytes during 1990s [1]. In fact, this achievement leads to expansion of our perception from physiological activities of adipose tissue so that it is either energy storage or hormone secreting organ [2]. The chromosome 3q27 with three exons and two introns is locus related to adiponectin gene and ultimately a protein of 247 amino acids obtained from it $[1,3]$. The Cys39 is a main region for adiponectin oligomerization so that results in production of its two forms, including low molecular weight (LMW) as two trimers and high molecular weight (HMW) as four to six trimmers [4]. The concentration of adiponectin circulation is about 2-20 $\mathrm{mg} / \mathrm{ml}$ and as comprised $0.05 \%$ of total serum protein can considers as a protein with high concentration in serum [5]. When its serum level is within normal range, any fluctuant in homeostasis of glucose, triglycerides, and free fatty acids has been not observed, while followed by its reduction occurs many problem related to energy homeostasis such as type 2diabetes, metabolic syndrome, 


\section{Diabetes and Obesity International Journal}

obesity, and atherosclerosis [5-8]. Because, it has been reported molecules derived by adipose tissue have a pivotal role in pathophysiology of insulin resistance, obesity, and atherosclerosis [5]. Inflammation is considers as relating factor between obesity and adiponectin reduction, also the expansion of inflammation leads to insulin resistance and cardiovascular disease [9]. In addition, the prevention of type two diabetes and cardiovascular disease through proceeding related to increase level of circulating adiponectin such as lowcalorie, high-unsaturated fat diet and/or exercise confirm important role of adiponectin in energy homeostasis [10]. Thus, to stable adiponectin serum level adiponectin through pharmacotherapy interventions is a solution for treatment of many disease so that achievement using PPAR- $\delta$ agonists and statins have been obtained $[11,12]$. The physiological action of adiponectin occurs through its binding to AdipoR1 and AdipoR2. These receptors stimulate phosphorylation of adenosine monophosphate protein kinase (AMPK), acetyl coenzyme A carboxylase (ACC) and peroxisome proliferators activated receptor (PPAR) signaling pathways in skeletal muscle (AdipoR1) and liver (AdipoR2) [13-16]. It have been reported that these receptors have different affinity for adiponectin so that the affinity of AdipoR1 is higher than AdipoR2 $[17,18]$. Given that their actions in energy homeostasis by increase of glucose uptake and fatty acid oxidation in skeletal muscle and glucose output reduction in liver, thus they are pivotal treatment goals to improve diabetes, obesity and cardiovascular disease [19,20]. For example, diabetes induction leads to increase of adiponectin receptor 1 expression in heart and skeletal muscle and reduction of adiponectin level in serum. In addition, insulin administration is requiring or preserving adiponectin receptor 1 in normal range. Surprisingly, diabetes induction was not affective on gene expression of adiponectin receptor 2 in liver $[21,22]$. In study on nondiabetic subject (with or without family history of Type 2 diabetes) has been determined that gene expression of both adiponectin receptors reduce in non-diabetic with family history of T2D. This study indicates that they can be good predicators for diabetes diagnosis [23]. The expression of adiponectin receptors has a positive correlation with PPAR- $\delta$ expression. Moreover, donors' fasting plasma triglycerides has a negative association with AdipoR1 expression in myocyte [24].

\section{Review Method}

In this study, we reviewed the effect of endogenous and exogenous factors on adiponectin regulation and its receptors using to search databases such as PubMed, science direct, and web of Science from 2000 to now.

\section{Endogenous Factors}

Insulin resistant along with increase of TNF- $\alpha$ and IL-6 are the factors that can be affective in adiponectin level reduction because in a study was determined that adiponectin serum level reduced in obese diabetic patients. In addition, this study was showed that insulin leads to adiponectin releasing from adipose tissue only in lean individuals; therefore increase of TNF- $\alpha$ and IL-6 from adipose tissue during obesity prevents adiponectin secretion in normal range from adipose tissue [25]. Probably, the major portion of serum adiponectin is related to omental cells because it has been determined that treatment with insulin or rosiglitazone as alone or combinatorial results in adiponectin secretion increase from omental cells compared to subcutaneous adipocytes. Moreover, there is a direct or indirect relationship in adiponectin secretion from omental cells or subcutaneous adipocytes to body mass index, respectively [26]. Nevertheless, in a study was confirmed that insulin infusion equally leads to suppression of adiponectin secretion both lean and obese people and also treatment with BQ123 as a endothelin receptor antagonism was indicated that endothelin has not any effect on adiponectin serum level during insulin infusion [27]. Increase of adiponectin plasma level and mRNA in adipose tissue related to lean people and inversion relationship between adiponectin and cytokines-divided adipose tissue (IL-6, IL-8, and TNF- $\alpha$ ) indicate role of these cytokines in reduction of adiponectin level in obese people [28]. In addition, down-regulation of adiponectin after treatment with TNF- $\alpha$ in C57BL/6J mouse has been showed [29] and also adiponectin resistance in skeletal muscle result from during continuing inflammatory condition by treatment with TNF- $\alpha$ [30]. Adipocyte determination and differentiation-dependent factor 1 (ADD1)/sterol regulatory element-binding protein 1c (SREBP1c) transcription factor (ADD1/SREBP1c) is a regulatory factor of adiponectin gene expression so that it leads to increase of adiponectin mRNA [31]. Although increase of adiponectin serum level is associated with higher levels of testosterone and lower level of estradiol in serum but other probably, factors lead to difference in serum level of adiponectin in both genders [32]. Id3 as a helix-loop-helix factor binds to E47 as E-proteins so that results in inhibition of its binding to DNA. In addition, it can be a negative regulator of adiponectin gene expression, because its increase leads to reduction of adiponectin gene expression by interaction with E47 as SREBP-1c-mediated adiponectin promoter activation [33]. In a study was found that hypoxia inducible factor-1 (HIF-1) induces adiponectin gene expression in heart and specially white adipose tissue so that its production in 


\section{Diabetes and Obesity International Journal}

heart can improves ischemia/reperfusion injury during diabetes along with obesity [34]. It has also been reported that the protein family CTRPs (C1q/TNF-related proteins)as type of adipokines are effective on improvement of endothelial dysfunction through biding to adiponectin receptor- 1 . Therefore, adiponectin receptor-1 can consider as a therapeutic strategy [35]. Based on our study in relation to effect of thyroid hormones on adiponectin gene expression at adipose tissue determined that induction of hyperthyroidism by levothyroxine results in significantly increase of adiponectin mRNA in adipose tissue [36]. In addition, thyroid hormones increase AdipoR1 and AdipoR2mRNA levels according to our obtained results [37].

\section{Exogenous Factors}

Treatment with exogenous growth hormone (rAAV2/1CMV-GH1) increases gene expression of adipoR2 in liver, HMW adiponectin in liver and serum, respectively but there was not any change in adipoR1 expression after injection of rAAV2/1-CMV-GH1 in skeletal muscle [38]. Administration of CL316, 243 as a $\beta_{3}$-adrenergic agonist markedly increases both serum level and adiponectin mRNA in white adipose tissue [39]. It has also been reported that both CL-316,243 and BRL37344 as $\beta$ adrenoceptor agonists upregulate adiponectin receptor 2 (not receptor 1) in white adipose tissues related to epididymal and subcutaneous [40]. Peroxisome proliferator-activated receptor- $\gamma$ (PPAR- $\gamma$ ) agonists (thiazolidinediones) are important factors for adiponectin level increase. Indeed, they increase interaction between PPAR-responsive element to retinoid $\mathrm{X}$ receptor or liver receptor homolog-1 in adipose tissue [41]. On the other hand, rosiglitazone as a peroxisome proliferators activated receptor $\gamma$ (PPAR $\gamma$ ) agonist leads to increase expression of adiponectin and its receptors (AdipoR1 and AdipoR2) in adult rat, thus PPARy is a main regulator for adiponectin [42]. In addition, increase of adiponectin level results from troglitazone administration in diabetic and non-diabetic individuals' weather lean or obese [43]. Given that Citrus aurantium L (particularly its isolated compound such as naringenin and hesperetin) is used to treat cardiovascular, in a study the effect of naringenin and hesperetin on adiponectin expression was performed. The results were showed that these flavonoids have antiatherogenic property through adiponectin expression up-regulation [44]. The other type of flavonoids have also are adiponectin regulator for example kaempferol glycosides CO-1 and CO-2 isolated from C. osmophloeum leaves induce adiponectin secretion in differentiated mouse 3T3-L1 adipocytes [45]. Tongqiaohuoxue decoction (THD) is a water extract prepared from eight herb species that numerous utilizing in traditional medicine particularly induction of adiponectin secretion from adipose tissue [46]. In a study, the effect of methanolic leaf extract of Gymnema sylvestre on expression of adiponectin in 3T3 L1 murine adipocyte cell line was evaluated. The result was showed that it markedly leads to increase of adiponectin gene expression and can considers as an adiponectin regulator [47]. In addition, chlorogenic acid has anti-diabetic effect due to increase of adiponectin level in adipose tissue and improvement of signaling pathways of its receptor [48]. The using of natural product as adiponectin regulator can be a good strategy to treat adiponectin-related disease so that has been confirmed that oleic acid and hydroxytyrosol prevent TNF- $\alpha$-induced suppression of total adiponectin secretion through abrogation of TNF- $\alpha$ stimulated JNK phosphorylation [49]. Dietary saturated fatty acids specially palmitic acid up-regulate mRNA and protein levels of hepatic AdipoR2 through increase level of Fox01 protein, inhibition of its hyperacetylation and enhancement of its association with the AdipoR2 promoter in the livers [50]. In a study, we confirmed that treatment with ginsenoside $\mathrm{Rb} 1$ results in activation of adiponectin signaling in $\mathrm{C} 2 \mathrm{C} 12$ myocytes so that it increased noticeably gene expression of AdipoR1 and AdipoR2 [51] (Table 1).

\begin{tabular}{|c|c|}
\hline Endogenous regulators & Exogenous regulators \\
\hline TNF- $\alpha \downarrow$ & Exogenous growth hormone $\uparrow$ \\
\hline IL-6 $\downarrow$ & CL316, 243 (a $\beta_{3}$-adrenergic agonist) $\uparrow$ \\
\hline IL-8 $\downarrow$ & BRL37344 (a $\beta_{3}$-adrenergic agonist) $\uparrow$ \\
\hline Insulin $\uparrow$ or $\downarrow *$ & Thiazolidinediones $\uparrow$ \\
\hline ADD1/SREBP1c $\uparrow$ & Rosiglitazone $\uparrow$ \\
\hline Testosterone $\uparrow$ & Troglitazone $\uparrow$ \\
\hline Estradiol $\downarrow$ & Antioxidants(Naringenin) $\uparrow$ \\
\hline Id3 (a helix-loop-helix factor) $\downarrow$ & Hesperetin $\uparrow$ \\
\hline
\end{tabular}




\section{Diabetes and Obesity International Journal}

\begin{tabular}{|c|c|}
\hline HIF-1 $\uparrow$ & Kaempferol glycosides CO-1 and CO-2 $\uparrow$ 国 \\
\hline C1q/TNF-related proteins $\uparrow$ & Tongqiaohuoxue decoction \\
\hline \multirow{3}{*}{ Thyroid hormone } & Methanolic leaf extract of Gymnema sylvestre \\
\cline { 2 - 2 } & Chlorogenic acid \\
\cline { 2 - 2 } & Oleic acid $\uparrow$ \\
\cline { 2 - 2 } & Hydroxytyrosol $\uparrow$ \\
\cline { 2 - 2 } & Palmitic acid $\uparrow$ \\
\cline { 2 - 2 } & Ginsenoside $\mathrm{Rb} 1 \uparrow$ \\
\hline
\end{tabular}

Table1: The endogenous and exogenous factors affective on adiponectin level.

TNF- $\alpha$ : Tumor necrosis factor-alpha; IL-6: Interleukin-6; IL-8: Interleukin-8; ADD1/SREBP1c: Adipocyte determination and differentiation-dependent factor 1 (ADD1)/sterol regulatory element-binding protein 1c (SREBP1c) transcription factor; HIF-1: Hypoxia inducible factor- $1 .{ }^{*}$ In relation to insulin have been reported both additive and decreasing effects.

\section{Conclusions}

Here, we reviewed several endogenous and exogenous adiponectin regulators. This study can be useful to understand pivotal role of adiponectin and its receptors in disease related to energy homeostasis such as insulin resistant and obesity. Given that our review, adiponectin and its receptors can be important treatment goals and regulated through drugs or active compounds derived herbs. Therefore, we suggest that specifically attend to adiponectin and its receptors in further studies for disease treatment.

\section{Declarations}

\section{Acknowledgements}

Us acknowledgements and gratefulness at the beginning and at last is to god who gave us the gift of the mind. The authors thank Young Researchers and Elite Club, Yasooj Branch, Islamic Azad University due to cooperation in this study.

\section{Conflict of interest statement}

The authors declare that there is no conflict of interest regarding this study.

\section{Financial support and sponsorship}

This study was supported by the authors named in this article.

\section{Contribution of Authors}

This work was done by the authors named in this article and all liabilities pertaining to claims relating to the content of this article was borne by the authors named in this article.

\section{Ethical approval}

This research does not contain any studies with human participants or animals and was performed by the authors alone.

\section{References}

1. Scherer PE, Williams S, Fogliano M, Baldini G, Lodish HF (1995) A novel serum protein similar to C1q, produced exclusively in adipocytes. J Biol chem 270(45): 26746-26749.

2. Ahima RS, Flier JS (2000) Adipose tissue as an endocrine organ. Trends in Endocrinology \& Metabolism 11(8): 327-332.

3. Kissebah AH, Sonnenberg GE, Myklebust J, Goldstein M, Broman K, et al. (2000) Quantitative trait loci on chromosomes 3 and 17 influence phenotypes of the metabolic syndrome. Proceedings of the National Academy of Sciences 97(26): 14478-14483.

4. Pajvani UB, Du X, Combs TP, Berg AH, Rajala MW, et al. (2003) Structure-function studies of the adipocytesecreted hormone Acrp30/adiponectin implications for metabolic regulation and bioactivity. Journal of Biological Chemistry 278(11): 9073-9085.

5. Lihn A, Pedersen SB, Richelsen B (2005) Adiponectin: action, regulation and association to insulin sensitivity. Obesity reviews 6(1): 13-21. 


\section{Diabetes and Obesity International Journal}

6. Shehzad A, Iqbal W, Shehzad O, Lee YS (2012) Adiponectin: regulation of its production and its role in human diseases. Hormones (Athens) 11(1): 8-20.

7. Li S, Shin HJ, Ding EL, van Dam RM (2009) Adiponectin levels and risk of type 2 diabetes: a systematic review and meta-analysis. Jama 302(2): 179-188.

8. Pischon T, Girman CJ, Hotamisligil GS, Rifai N, Hu FB, et al. (2004) Plasma adiponectin levels and risk of myocardial infarction in men. Jama 291(14): 17301737.

9. Fantuzzi G (2013) Adiponectin in inflammatory and immune-mediated diseases. Cytokine 64(1): 1-10.

10. Esposito K, Pontillo A, Di Palo C, Giugliano G, Masella $M$, et al. (2003) Effect of weight loss and lifestyle changes on vascular inflammatory markers in obese women: a randomized trial. Jama 289(14): 17991804.

11. Yang WS, Jeng CY, Wu TJ, Tanaka S, Funahashi T, et al. (2002) Synthetic peroxisome proliferator-activated receptor- $\gamma$ agonist, rosiglitazone, increases plasma levels of adiponectin in type 2 diabetic patients. Diabetes care 25(2): 376-380.

12. Koh KK, Quon MJ, Han SH, Lee Y, Kim SJ, et al. (2009) Differential metabolic effects of pravastatin and simvastatin in hypercholesterolemic patients. Atherosclerosis 204(2): 483-490.

13. Kadowaki T, Yamauchi $\mathrm{T}$ (2005) Adiponectin and adiponectin receptors. Endocrine reviews 26(3): 439451.

14. Yamauchi T, Kamon J, Waki H, Imai Y, Shimozawa N, et al. (2003) Globular adiponectin protected ob/ob mice from diabetes and ApoE-deficient mice from atherosclerosis. Journal of Biological Chemistry 278(4): 2461-2468.

15. Tsuchida A, Yamauchi T, Ito Y, Hada Y, Maki T, et al. (2004) Insulin/Foxo1 pathway regulates expression levels of adiponectin receptors and adiponectin sensitivity. Journal of Biological Chemistry 279(29): 30817-30822.

16. Fischer-Posovszky P, Wabitsch M, Hochberg Z (2007) Endocrinology of adipose tissue-an update. Hormone and metabolic research 39(05): 314-321.
17. Kadowaki T, Yamauchi T, Kubota N, Hara K, Ueki K, et al. (2006) Adiponectin and adiponectin receptors in insulin resistance, diabetes, and the metabolic syndrome. The Journal of clinical investigation 116(7): 1784-1792.

18. Yamauchi T, Kamon J, Minokoshi Ya, Ito Y, Waki H, et al. (2002) Adiponectin stimulates glucose utilization and fatty-acid oxidation by activating AMP-activated protein kinase. Nature medicine 8(11): 1288-1295.

19. Berg AH, Combs TP, Scherer PE (2002) ACRP30/adiponectin: an adipokine regulating glucose and lipid metabolism. Trends in Endocrinology \& Metabolism 13(2): 84-89.

20. Fruebis J, Tsao T-S, Javorschi S, Ebbets-Reed D, Erickson MRS, et al. (2001) Proteolytic cleavage product of $30-\mathrm{kDa}$ adipocyte complement-related protein increases fatty acid oxidation in muscle and causes weight loss in mice. Proceedings of the National Academy of Sciences 98(4): 2005-2010.

21. Guo Z, Xia Z, Yuen VG, McNeill JH (2007) Cardiac expression of adiponectin and its receptors in streptozotocin-induced diabetic rats. Metabolism 56(10): 1363-1371.

22. Sun X, He J, Mao C, Han R, Wang Z, et al. (2008) Negative regulation of adiponectin receptor 1 promoter by insulin via a repressive nuclear inhibitory protein element. FEBS letters 582(23-24): 3401-3407.

23. Civitarese A, Jenkinson C, Richardson D, Bajaj M, Cusi $\mathrm{K}$, et al. (2004) Adiponectin receptors gene expression and insulin sensitivity in non-diabetic Mexican Americans with or without a family history of Type 2 diabetes. Diabetologia 47(5): 816-820.

24. Ordelheide AM, Heni M, Gommer N, Gasse L, Haas C, et al. (2011) The myocyte expression of adiponectin receptors and PPAR $\delta$ is highly coordinated and reflects lipid metabolism of the human donors. Experimental diabetes research 2011: 692536.

25. Hajri T, Tao H, Wattacheril J, Marks-Shulman $\mathrm{P}$, Abumrad NN (2011) Regulation of adiponectin production by insulin: interactions with tumor necrosis factor- $\alpha$ and interleukin-6. American Journal of Physiology-Endocrinology and Metabolism 300(2): E350-E60.

26. Motoshima H, Wu X, Sinha MK, Hardy VE, Rosato EL, et al. (2002) Differential regulation of adiponectin 


\section{Diabetes and Obesity International Journal}

secretion from cultured human omental and subcutaneous adipocytes: effects of insulin and rosiglitazone. The Journal of Clinical Endocrinology \& Metabolism 87(12): 5662-5667.

27. Brame LA, Considine RV, Yamauchi M, Baron AD, Mather KJ (2005) Insulin and endothelin in the acute regulation of adiponectin in vivo in humans. Obesity research 13(3): 582-588.

28. Bruun JM, Lihn AS, Verdich C, Pedersen SB, Toubro S, et al. (2003) Regulation of adiponectin by adipose tissue-derived cytokines: in vivo and in vitro investigations in humans. American Journal of Physiology-Endocrinology and Metabolism 285(3): E527-E33.

29. Li L, Yang G, Shi S, Yang M, Liu H, et al. (2009) The adipose triglyceride lipase, adiponectin and visfatin are downregulated by tumor necrosis factor- $\alpha$ (TNF$\alpha$ ) in vivo. Cytokine 45(1): 12-19.

30. Sente T, Van Berendoncks AM, Fransen E, Vrints CJ, Hoymans VY (2016) Tumor necrosis factor- $\alpha$ impairs adiponectin signalling, mitochondrial biogenesis, and myogenesis in primary human myotubes cultures. American Journal of Physiology-Heart and Circulatory Physiology 310(9): H1164-H1175.

31. Seo JB, Moon HM, Noh MJ, Lee YS, Jeong HW, et al. (2004) Adipocyte determination-and differentiationdependent factor 1 sterol regulatory elementbinding protein 1c regulates mouse adiponectin expression. Journal of biological chemistry 279(21): 22108-22117.

32. Laughlin G, Barrett-Connor E, May S (2007) Sexspecific determinants of serum adiponectin in older adults: the role of endogenous sex hormones. International journal of obesity 31(3): 457-465.

33. Doran AC, Meller N, Cutchins A, Deliri H, Slayton RP, et al. (2008) The helix-loop-helix factors Id3 and E47 are novel regulators of adiponectin. Circulation research 103(6): 624-634.

34. Natarajan R, Salloum FN, Fisher BJ, Kukreja RC (2008) Hypoxia inducible factor-1 upregulates adiponectin in diabetic mouse hearts and attenuates post-ischemic injury. Journal of cardiovascular pharmacology 51(2): 178-187.

35. Zheng Q, Yuan Y, Yi W, Lau WB, Wang Y, et al. (2011) C1q/TNF-related proteins, a family of novel adipokines, induce vascular relaxation through the adiponectin receptor-1/AMPK/eNOS/nitric oxide signaling pathway. Arteriosclerosis, thrombosis, and vascular biology 31(11): 2616-2623.

36. Seifi S, Tabandeh MR, Nazifi S, Saeb M, Shirian S, et al. (2012) Regulation of adiponectin gene expression in adipose tissue by thyroid hormones. Journal of physiology and biochemistry 68(2): 193-203.

37. Seifi S, Nazifi S, Tabandeh MR, Saeb M (2013) AdipoR1 and AdipoR2 gene expression are regulated by thyroid hormones in adipose tissue. Molecular and cellular biochemistry 377(1-2): 55-63.

38. Qin Y, Tian Y-P (2010) Hepatic adiponectin receptor $\mathrm{R} 2$ expression is up-regulated in normal adult male mice by chronic exogenous growth hormone levels. Mol Med Rep 3(3): 525-530.

39. Zhang Y, Matheny M, Zolotukhin S, Tumer N, Scarpace PJ (2002) Regulation of adiponectin and leptin gene expression in white and brown adipose tissues: influence of $\beta 3$-adrenergic agonists, retinoic acid, leptin and fasting. Biochim Biophys Acta 1584(2): 115-122.

40. Fu L, Isobe K, Zeng Q, Suzukawa K, Takekoshi K, et al. (2007) $\beta$-adrenoceptor agonists downregulate adiponectin, but upregulate adiponectin receptor 2 and tumor necrosis factor- $\alpha$ expression in adipocytes. European journal of pharmacology 569(1): 155-162.

41. Iwaki M, Matsuda $M$, Maeda $N$, Funahashi $T$, Matsuzawa Y, et al. (2003) Induction of adiponectin, a fat-derived antidiabetic and antiatherogenic factor, by nuclear receptors. Diabetes 52(7): 1655-1663.

42. Ding G, Qin Q, He N, Francis-David SC, Hou J, et al. (2007) Adiponectin and its receptors are expressed in adult ventricular cardiomyocytes and upregulated by activation of peroxisome proliferator-activated receptor $\gamma$. Journal of molecular and cellular cardiology 43(1): 73-84.

43. Joseph GY, Javorschi S, Hevener AL, Kruszynska YT, Norman RA, et al. (2002) The effect of thiazolidinediones on plasma adiponectin levels in normal, obese, and type 2 diabetic subjects. Diabetes 51(10): 2968-2974.

44. Liu L, Shan S, Zhang K, Ning ZQ, Lu XP, et al. (2008) Naringenin and hesperetin, two flavonoids derived from Citrus aurantium up-regulate transcription of adiponectin. Phytotherapy Research. 22(10): 14001403. 


\section{Diabetes and Obesity International Journal}

45. Lee MJ, Rao YK, Chen K, Lee YC, Tzeng YM (2009) Effect of flavonol glycosides from Cinnamomum osmophloeum leaves on adiponectin secretion and phosphorylation of insulin receptor- $\beta$ in 3T3-L1 adipocytes. Journal of ethnopharmacology 126(1): 79-85.

46. Kim SH, Park HS, Hong MJ, Yoo JY, Lee H, et al. (2016) Tongqiaohuoxue decoction ameliorates obesityinduced inflammation and the prothrombotic state by regulating adiponectin and plasminogen activator inhibitor-1. Journal of Ethnopharmacology 192: 201209.

47. Kumar PM, Venkataranganna MV, Manjunath K, Viswanatha GL, Ashok G (2016) Methanolic leaf extract of Gymnema sylvestre augments glucose uptake and ameliorates insulin resistance by upregulating glucose transporter-4, peroxisome proliferator-activated receptor-gamma, adiponectin, and leptin levels in vitro. Journal of intercultural ethnopharmacology 5(2): 146-152.
48. Jin S, Chang C, Zhang L, Liu Y, Huang X, et al. (2015) Chlorogenic acid improves late diabetes through adiponectin receptor signaling pathways in $\mathrm{db} / \mathrm{db}$ mice. PloS one 10(4): e0120842.

49. Scoditti E, Massaro M, Carluccio MA, Pellegrino M, Wabitsch M, et al. (2015) Additive regulation of adiponectin expression by the Mediterranean diet olive oil components oleic acid and hydroxytyrosol in human adipocytes. PloS one 10(6): e0128218.

50. Liang X, Hu M, Rogers CQ, Shen Z, You M (2011) Role of SIRT1-Fox01 signaling in dietary saturated fatdependent upregulation of liver adiponectin receptor 2 in ethanol-administered mice. Antioxidants \& redox signaling 15(2): 425-435.

51. Tabandeh MR, Jafari H, Hosseini SA, Hashemitabar M (2015) Ginsenoside Rb1 stimulates adiponectin signaling in C2C12 muscle cells through up-regulation of AdipoR1 and AdipoR2 proteins. Pharmaceutical biology 53(1): 125-132. 